\title{
Analysis of the Influence of an Interpersonal Communication Doctors Specialist on Patient Satisfaction in Investigation
}

\author{
Anggraini Sariputri ${ }^{1}$, Sri Lestari Ramadhani Nasution ${ }^{2}$, Ermi Girsang ${ }^{3}$, \\ Chrismis Novalinda Gintin ${ }^{4}$
}

${ }^{1}$ Postgraduate Student Public Health, Faculty of Medical, Universitas Prima Indonesia
2,4 Lecturer of Master Public Health Faculty of Medical, Universitas Prima Indonesia
${ }^{3}$ Lecturer of Medical Tropical Science, Faculty of Medical, Universitas Prima Indonesia

Corresponding Author: Anggraini Sariputri

\begin{abstract}
The effective communication that occurs between doctors and patients will create a sense of comfort for the patient with medical therapy given by the doctor when examining the inpatient room of the Royal Prima Hospital, Medan. This paper analyzes the influence of interpersonal communication of specialist doctors on patient satisfaction at Royal Prima Medan Hospital. This type of research is quantitative with a study-descriptive research design. The population in this study were all inpatients at the Royal Prima Medan Hospital. The research sample was 80 hospitalized patients. The analysis of research data was univariate, bivariate, and multivariate analysis. The results of the study with the Fisher Exact test explained that there was a relationship between interpersonal communication of specialist doctors and patient satisfaction with a value of $p=0.002$. In this study, it can be concluded that there is an influence between the doctor's interpersonal communication on patient satisfaction in the inpatient room of Royal Prima Medan Hospital. It is recommended for the hospital to improve the quality of health services, especially in terms of interpersonal communication between doctors and patients in the inpatient room.
\end{abstract}

Keywords: interpersonal communication, patient satisfaction, hospital, doctor

\section{INTRODUCTION}

Hospitals in the concept of providing health services to the community should be complete individual services, health promotion efforts (promotive), prevention (preventive) without neglecting curativerehabilitative efforts, as well as providing inpatient, outpatient, and emergency service units.

Everyone who suffers from a disease definitely wants to be healthy so that the hospital will have a very big role in improving the health status of the patient (Permenkes RI No.4 of 2018). Based on the Regulation of the Minister of Health of the Republic of Indonesia No. 56 of 2016 concerning the hospital is a company or production that provides health services in all fields and types of diseases. The limitations of this service can be concluded that the quality of health services is conformity of health services with professional standards by utilizing resources properly so that all patient needs are met and the goal of achieving an optimal health degree can be achieved (Permenkes RI No.40 of 2018).

Currently the hospital is in a very competitive global atmosphere that demands a high quality of hospital services based on a clear and directed management concept, without a clear management concept, hospital development will run slowly. One of the current hospital service strategies is to 
approach the quality of health services that are oriented towards patient satisfaction. Patient satisfaction assessment strategies can be determined by the quality of health care providers felt by patients while in the hospital.

Patient satisfaction can be assessed starting from the admission of the patient when he first arrives until the patient returns from the hospital. Fulfilling these patient needs will have an impact on patient satisfaction with hospital health services, but health workers often do not realize that patient satisfaction with health services is a dimension of assessment of the quality of hospital services (Permenkes RI No.4 of 2018) Health services are considered to be able to satisfy users or patients if these health services can fulfill the patient's needs as a whole. If the patient feels that his needs are not being met, he will feel dissatisfied so that the patient will leave the service

The results of Syafitri's (2014) study show that low patient satisfaction in the hospital is due to poor communication by health workers. Poor communication between health workers can be seen from the number of patients who come to the hospital who feel less valued and cared for when examined by a doctor.

The role of the patient today has changed from passive to assertive, especially in terms of obtaining medical information and making medical decisions. This condition requires mastery of communication for a communicator in conveying messages to the communicant. Broadly speaking, the form of communication is divided into 4 , namely personal communication (intra-personal communication and interpersonal communication), group communication, mass communication, and media communication (Liliweri, 2015).

For the communication process about health to be effective and directed it can be done through the form of interpersonal communication which is one of the most effective forms of communication because between the communicant and the communicator can be face to face, so that a stimulus arises, namely messages or information conveyed by the communicant, which can be directly responded to or responded to at that time (Adhani, 2014). Interpersonal communication is communication that occurs between communicators and communicants that occurs directly face to face or not face to face. This interpersonal communication is considered more effective than other forms of communication because both parties can exchange information in the communication process as well as direct feedback from both of them according to their respective functions (Adhani, 2014).

Effective communication between health workers is communication that occurs between doctors and nurses to create a patient's sense of comfort towards medical therapy given by doctors, factors of doctor behavior towards patients, the doctor's ability to get and respect patient attention, availability of appropriate information and generate empathy and build trust. The patient turns out to be the key determinant in good comfort with medical therapy for patients in health services (Adhani, 2014) According to Devito in Adhani (2014), the effectiveness of interpersonal communication starts with five general qualities that are considered, namely openness, empathy (empathy), supportiveness, positive attitude (positiveness), and equality (equality). A doctor's interpersonal communication will be a benchmark for patient satisfaction in the hospital because doctors have a very important role in achieving patient satisfaction.

Doctors are medical personnel who have a very important role in maintaining the quality of health services in hospitals. namely as a service provider. because between the communicant and the communicator can directly face to face.

This is in line with the results of Siregar's (2016) study showing that interpersonal communication carried out by doctors and nurses (openness, empathy, 
supportive nature, positive nature, and equality) has an impact on patient satisfaction in taking medication. The results of research that are not much different are expressed by Caresya (2016) showing that the interpersonal communication provided by dentists is in the form of sympathy, listening to complaints, friendliness, positive attitudes, attention to make children satisfied with the services provided.

Doctors as human resources have an important role in running hospital operations and have a very significant contribution to the quality of service in the hospital, for this reason, doctors are required to have intellectual, interpersonal, technical skills, communication skills and have high moral values. Therefore, health services provided by doctors are an integral part of health services in hospitals. The phenomenon of low patient satisfaction based on patient complaint letters regarding health services provided by doctors, especially regarding communication made by doctors to patients, the researcher wants to research "an analysis of the influence of specialist doctors' interpersonal communication on BPJS patient satisfaction in the inpatient room of Hospital Royal Prima Medan ".

\section{COMMUNICATION}

Communication is the process of delivering messages using meaningful symbols from communicators to communicants with a specific purpose. The expected goals of the communication process are changes in the form of adding knowledge, changing opinions, strengthening opinions, and changing attitudes and behavior of communicants or known in three levels of change or effect of a communication process, namely: changes in thoughts (cognitive) changes in feelings (affective) and changes in behavior (behavioral) (Siregar, 2016).

According to Winnet in Liliweri (2015), communication is all human interaction activities that are human relationships accompanied by the transfer of several facts. In simple terms, it can be said that communication is the interaction or transaction between two people (Liliweri, 2015).

Humans are social creatures who live and carry out their entire life as individuals in social groups, communities, organizations, and societies. In everyday life, every human being interacts, building relationships, and social transactions with others. That is why humans cannot avoid interpersonal communication, group communication, organizational and public communication, and mass communication (Liliweri, 2015).

Interpersonal communication is communication that occurs between communicators and communicants that occurs directly face to face or not face to face. This interpersonal communication is considered more effective than other forms of communication because both parties can exchange information in the communication process as well as direct feedback from both of them according to their respective functions (Cangara, 2016).

For the communication process about health to be effective and directed it can be done through the form of interpersonal communication which is one of the most effective forms of communication because between the communicant and the communicator can be face to face, so that a stimulus arises, namely messages or information conveyed by the communicant, which can be directly responded to. or responded to at that time (Adhani, 2014).

Adhani's (2014) general theory of interpersonal communication can be seen from two definitions as:

1. Etymological definition of communication. Communication comes from Latin communication, and also comes from the word communis which means the same, in the sense that the word has the same meaning. So communication takes place when between the people involved there is a 
similarity in meaning about something that is communicated.

2. Understanding communication in terminology. Communication means the delivery of a statement by someone to another.

\subsection{Principles of Interpersonal Communication}

According to Devito in Adhani (2014) that to support the realization of good and harmonious interpersonal communication, communication continuity must meet the principles of inter-human communication or interpersonal communication, namely: 1. Openness (Openness) Openness refers to at least three aspects of interpersonal communication. First, effective interpersonal communicators must be open to the people they interact with.

This does not mean that one should immediately open up all of his biographies. While this may be interesting, it usually doesn't help with communication. On the other hand, there must be a willingness to open oneself to reveal information that would normally be hidden, provided this self-disclosure is appropriate. The second aspect of openness refers to the communicator's willingness to react honestly to the stimulus that comes. Silent, uncritical, and unresponsive people are generally participants in tedious conversations. We want people to react openly to what we say, and we have a right to expect this. There is nothing worse than indifference, even more, pleasant disagreement. We show openness by reacting spontaneously to others.

The third aspect concerns the "ownership" of feelings and thoughts. Being open in this sense is acknowledging that the feelings and thoughts that you bring up are indeed yours and you are responsible for them (Adhani, 2014) Hutagaol's (2014) research results show that the openness of health workers in communicating on family satisfaction of outpatients at Pandan Tengah Health Center. The results of Siregar's research (2016) show that the lack of openness of doctors in communicating with patients makes patients feel dissatisfied with the health services provided, patients feel that doctors are not open in explaining the disease suffered by patients, it will make the patient's family disappointed with the service provided by the doctor.

\subsection{Definition of Patient}

Satisfaction Siregar (2016) defines satisfaction as feeling happy, feeling relieved, happy, and so on because his heart's desire has been fulfilled. Customer (patient) satisfaction depends on the perceived performance of the product (service) in delivering value relative to the expectations of the buyer (service user). If the performance or performance of health services matches or even exceeds expectations, the buyer (service user) will be satisfied. A smart (industrial) company has a goal of making customers (patients) happy (feeling satisfied), not only by promising what they have given but giving more than what has been promised (Shinta, 2015).

Patients are sick people who are treated by doctors and other health workers in the hospital. Satisfaction is someone's a happy feeling that comes from a comparison between pleasure in an activity and a product with expectations (Nursalam, 2015). Customer (patient) satisfaction is a function of the view of product performance and buyer expectations. To achieve patient satisfaction, the hospital must create and manage a system or a way to get more patients and have the ability to retain their patients. Many companies aim at total customer satisfaction (TCS), based on this goal make marketing managers have a quality-centered responsibility, that is, they must participate in formulating strategies and policies designed to help companies excel in the competition through features of total quality (Shinta, 2015). According to Sebayang (2014), patient satisfaction is a subjective value of the quality of services provided subjectively and objectively. 
Patient satisfaction is not only based on the patient's experience and the physical situation at that time but is based on the truth and objective reality.

Pohan (2016) states that patient satisfaction is the level of patient feelings that arise as a result of the health service performance he gets after the patient compares with what he expects. Based on the descriptions of several experts above, it can be concluded that patient satisfaction is the result of an assessment in the form of an emotional response (feelings of pleasure and satisfaction) to the patient due to the fulfillment of expectations or desires in using and receiving nurse services.

\section{METHODS OF RESEARCH}

The type of data in this study consists of primary data and secondary data. Primary data collection was carried out by structured interviews using a questionnaire about interpersonal communication of specialist doctors and patient satisfaction of inpatient BPJS and also used interview guidelines to conduct in-depth interviews.

Primary data is all data obtained from observations, observations and direct interviews using interview guidelines and interviews with questionnaires with inpatients at the Royal Prima Medan General Hospital regarding service satisfaction that has been compiled in the form of an instrument of assessment elements and other things related to the assessment of interpersonal communication doctors at the Royal General Prima Medan Hospital.

The type of data in this study consists of primary data and secondary data. Primary data collection was carried out by structured interviews using a questionnaire about interpersonal communication of specialist doctors and patient satisfaction of inpatient BPJS and also used interview guidelines to conduct in-depth interviews.

Primary data is all data obtained from observations, observations, and direct interviews using interview guidelines and interviews with questionnaires with inpatients at the Royal Prima Medan General Hospital regarding service satisfaction that has been compiled in the form of an instrument of assessment elements and other things related to the assessment of interpersonal communication doctors at the Royal General Prima Medan Hospital.

Secondary data in this study are all data obtained from document notes, reports, notebooks, archives, pictures, personal and official documentation related to patient satisfaction and interpersonal communication of specialist doctors at the Royal Prima General Hospital Medan.

\subsection{Validity and Reliability Test a. Test the Validity and Reliability of the Questionnaire}

The validity test aims to determine the extent to which a measure or value that indicates the level of reliability or validity of a measuring instrument by measuring the correlation between the variable or item and the total variable score in the reliability analysis with the corrected item-total correlation value as count, it is said to be valid if the value rcount> rtable. and vice versa. The rtable value in this study used a significance level of $95 \%$, then for a sample of 20 people tested, the rtable value was 0.576 .

Data reliability is an index that shows the extent to which a measuring device can show accuracy and reliability by using the Cronbach's Alpha method, which is to analyze the reliability of the measuring instrument from one measurement provided that if rcount> rtabel is declared reliable (Sugiyono, 2017). Validity and reliability tests were carried out on 15 inpatients at Bunda Thamrin Hospital, Medan.

\section{b. Variable and Operation}

The independent variable in this study is the doctor's interpersonal communication, while the dependent variable is the satisfaction of BPJS patients in the inpatient room of the Royal Prima 
Medan General Hospital. The operational definition of this research is

1. Openness (Openness) is the ability to open up a doctor at the Royal Prima Medan General Hospital in terms of disclosing clear health information, giving spontaneous reactions to patient/client responses, and delivering responsible information.

2. Empathy (Empathy) is the ability of doctors at the Royal Prima Medan General Hospital in understanding patients/clients, their feelings and attitudes, as well as their hopes and desires for health. 3. Supportiveness is the attitude shown by health workers in supporting patients/clients in overcoming health problems, students, to convey messages
3. Positive attitude (Positiveness) is a positive treatment shown by doctors of the Royal Prima Medan General Hospital in conveying messages about health

4. Equality (Equality) is the ability of doctors at the Royal Prima Medan General Hospital to create an atmosphere, where patients/clients feel like they are equal to health workers so that messages conveyed about health can be conveyed.

5. Satisfaction is the patient's response as an evaluation of the interpersonal communication of doctors at the Royal Prima Medan General Hospital, which is felt as fulfilling their expectations.

Tabel 1. Variable and Definition Of Operational

\begin{tabular}{|c|c|c|c|c|}
\hline Variable & Definition Of Operational & Tools & $\begin{array}{l}\text { Scala } \\
\text { Measure }\end{array}$ & Value \\
\hline $\begin{array}{l}\text { Variable } \\
\text { Independent } \\
\text { Interpersonal } \\
\text { Communication: } \\
\text { Openess }\end{array}$ & $\begin{array}{l}\text { Willingness to open up } \\
\text { in conveying information }\end{array}$ & questionnaire & Ordinal & $\begin{array}{l}\text { S: }>80-100 \% \\
\text { P: }>60-80 \% \\
R:>40-60 \% \\
\text { TP: }>20-40 \% \\
\text { STP: }>0-20\end{array}$ \\
\hline Empathy & Feel what other people feel & questionnaire & Ordinal & $\begin{array}{l}\text { SP: }>80-100 \% \\
\text { P: }>60-80 \% \\
\text { R }:>40-60 \% \\
\text { TP: }>20-40 \% \\
\text { STP: }>0-20\end{array}$ \\
\hline 3.Supportiveness & $\begin{array}{l}\text { Attitudes that give someone enthusiasm or } \\
\text { motivation }\end{array}$ & questionnaire & Ordinal & $\begin{array}{l}\text { 1. SP: }>80-100 \% \\
\text { 2. P: }>60-80 \% \\
\text { 3. R : }>40-60 \% \\
\text { 4. TP: }>20-40 \% \\
\text { 5. STP:>0-20 }\end{array}$ \\
\hline 4. Positiveness & $\begin{array}{l}\text { Encourage that encourages people to make } \\
\text { up something }\end{array}$ & questionnaire & Ordinal & $\begin{array}{l}\text { 1. SP: }>80-100 \% \\
\text { 2. P: }>60-80 \% \\
\text { 3. R : }>40-60 \% \\
\text { 4. TP: }>20-40 \% \\
\text { 5. STP: }>0-20\end{array}$ \\
\hline 5.Equality & $\begin{array}{l}\text { that both parties are equally valuable and } \\
\text { valuable }\end{array}$ & questionnaire & Ordinal & $\begin{array}{l}\text { 1. SP: }>80-100 \% \\
\text { 2. P: }>60-80 \% \\
\text { 3. R }:>40-60 \% \\
\text { 4. TP: }>20-40 \% \\
\text { 5. STP: }>0-20\end{array}$ \\
\hline 6. Variable Dependent & $\begin{array}{l}\text { As a feeling of pleasure, a feeling of relief, } \\
\text { joy and so on because his heart's desire has } \\
\text { been fulfilled }\end{array}$ & questionnaire & Ordinal & $\begin{array}{l}\text { 1. SP: }>80-100 \% \\
\text { 2. P: }>60-80 \% \\
\text { 3. R : }>40-60 \% \\
\text { 4. TP: }>20-40 \% \\
\text { 5. STP: }>0-20\end{array}$ \\
\hline
\end{tabular}

\subsection{Measurement Aspects}

The method of measurement is by measuring the independent variables, namely interpersonal communication of specialist doctors and the dependent variable, namely the satisfaction of BPJS patients in the inpatient room of the Royal Prima General Hospital, Medan.

The use of measuring instruments in research must be validity and reliability, this measuring tool can be in the form of directions and guidance with the question: is the measuring instrument used can measure 
what will be measured, whether the measuring instrument has covered all or some of the phenomena to be measured, Are all the items in the instrument able to be understood by all respondents, are there any terms in the item that are biased or have multiple meanings. This question can check the validity and reliability of a measuring instrument.

This study uses the validity of the Pearson product moment correlation instrument with a significance of 0.05 . Reliability coefficient is an important indicator of an instrument's quality. A measurement that cannot be trusted if it does not provide sufficient tests of the investigator's hypothesis. If the data is incorrect against the confirmation of the predictions, the instrument is probably unreliable. Interpretation for comparing group levels, coefficients ranging from 0.70 are generally adequate, although coefficients of 0.80 or greater are desirable.

The method of measurement is by measuring the independent variables, namely interpersonal communication of specialist doctors, and the dependent variable, namely the satisfaction of BPJS patients in the inpatient room of the Royal Prima General Hospital, Medan.

The use of measuring instruments in research must be valid and reliable, this measuring tool can be in the form of directions and guidance with the question: is the measuring instrument used can measure what will be measured, whether the measuring instrument has covered all or some of the phenomena to be measured, Are all the items in the instrument able to be understood by all respondents, are there any terms in the item that are biased or have multiple meanings. This question can check the validity and reliability of a measuring instrument.

This study uses the validity of the Pearson product-moment correlation instrument with a significance of 0.05 . The reliability coefficient is an important indicator of an instrument's quality. A measurement that cannot be trusted if it does not provide sufficient tests of the investigator's hypothesis. If the data is incorrect against the confirmation of the predictions, the instrument is probably unreliable. Interpretation for comparing group levels, coefficients ranging from 0.70 are generally adequate, although coefficients of 0.80 or greater are desirable.

\section{ANALYZE AND RESULT}

The bivariate analysis aims to determine whether there is an influence between a doctor's interpersonal communication (openness, empathy, supportive attitude, positive attitude, and equality) on the satisfaction of inpatients at Royal Prima General Hospital 2019. Bivariate analysis in research is data analysis used to see the influence of the doctor's interpersonal communication variables (openness, empathy, supportive attitude, positive attitude, and equality) on the satisfaction of inpatients at the Royal Prima General Hospital in 2019 using the Chi-square Fisher exact test. Bivariate analysis is presented in tabular and narrative form.

Table 2 describes the effect of doctor's interpersonal communication on patient satisfaction at the Royal Prima Medan General Hospital with $\mathrm{p}=0.002$ meaning that there is an influence between doctor's interpersonal communication and patient satisfaction.

Table 2. Describes the effect of doctor's interpersonal communication on patient satisfaction at the Royal Prima Medan General Hospital with $p=0.002$ meaning that there is an influence between doctor's interpersonal communication and patient satisfaction.

\begin{tabular}{|c|c|c|c|c|c|c|c|}
\hline \multirow{3}{*}{ Variable } & \multicolumn{6}{|l|}{ patient satisfaction } & \multirow{2}{*}{$\boldsymbol{P}$} \\
\cline { 2 - 8 } & Unsatisfaction & \multicolumn{2}{|c|}{ Satisfaction } & \multicolumn{2}{|c|}{ Value } & \\
\cline { 2 - 7 } & $\mathbf{n}$ & $\mathbf{\%}$ & $\mathbf{n}$ & $\mathbf{\%}$ & $\mathbf{N}$ & $\mathbf{\%}$ & \\
\hline Interpersonal Communication & & & & & & & \multirow{2}{*}{0,002} \\
\hline Not good & 35 & 78 & 15 & 22 & 45 & 100 & \\
\hline good & 25 & 71 & 10 & 29 & 35 & 100 & \\
\hline
\end{tabular}


This table is a cross between doctors' interpersonal communication on patient satisfaction at the Royal Prima Medan General Hospital, it is showing that of the 80 respondents who are mostly in the bad and dissatisfied communication category, 35 people $(78 \%)$,

The interpersonal communication category is not good with the category. Satisfied as many as 15 people (22\%), category of good interpersonal communication with dissatisfied as 25 people $(71 \%)$ and category of bad communication with categories of dissatisfaction as many as 10 people (29\%).

Multivariate analysis is used to determine which independent variable has the most influence on the dependent variable. Logistic regression can be used to analyze data sets with more than one independent/independent variable at nominal/ordinal scale against one dependent variable at a nominal scale. Multivariate analysis in this study using logistic regression analysis and presented in tabular and narrative form. The potential variables included in the model are those with $\mathrm{p}$ value $<0.25$.

Tables 2. Factors Affecting Interpersonal Communication Against Inpatient Satisfaction At Royal Prima Hospital Medan in 2019.

\begin{tabular}{|l|l|l|l|}
\hline & B & $\boldsymbol{P}$ & $\mathbf{E x p ( B )}$ \\
\hline Openness & $-0,668$ & 0,000 & 0,513 \\
\hline Attitude Support & $-0,668$ & 0,000 & 0,513 \\
\hline Positive Attitude & $-0,778$ & 0,001 & 0,513 \\
\hline Equality & $-0,788$ & 0,002 & 0,513 \\
\hline Constant & $-31,931$ & 0,002 & 0,002 \\
\hline
\end{tabular}

Based on the results of the logistic regression test, it was found that the variable that had an effect and the most dominant on the satisfaction of inpatients at the Royal Prima Hospital Medan was a supportive attitude with $\mathrm{p}=0.002$

The results of the logistic regression analysis showed that the supportive attitude variable influenced the satisfaction of inpatients at the Royal Prima Hospital Medan with $\mathrm{p}=0.002$, so it could be concluded that the supportive attitude variable became the most dominant variable affecting patient satisfaction.

\section{CONCLUSION}

In this discussion chapter, the researchers discuss

1. Physicians' interpersonal communication at the Royal Prima Medan General Hospital, 2. Inpatient satisfaction at the Royal Prima General Hospital and, 3.The effect of doctor's interpersonal communication on patient satisfaction at Royal Prima General Hospital.

This research was conducted in all surgical inpatient rooms, internal medicine, pediatric inpatient rooms, and obgen rooms at the Royal Prima Medan General Hospital. Researchers obtained a total of 80 inpatients.

\subsection{Doctor's Interpersonal Communication Based on Perceptions of Inpatients at the Royal Prima Medan General Hospital in 2019.}

Based on the results of research conducted at the Royal Prima Medan General Hospital in 2019 regarding interpersonal communication of doctors based on the perception of inpatients, the majority of doctors have poor interpersonal communication as many as 45 people and a minority of doctors have good interpersonal communication of doctors as many as 35 people.

Communication is the process of delivering messages using meaningful symbols from communicators to communicants with a specific purpose. The expected objectives of the communication process are changes in the form of adding knowledge, changing opinions, strengthening opinions, and changing attitudes and behavior of communicants or known in three levels of change or effect of a process communication, namely: changes in thoughts (cognitive) changes in feelings (affective), and changes in behavior (behavior).

Interpersonal communication is communication that occurs between 
communicators and communicants that occurs directly face to face or not face to face. This interpersonal communication is considered more effective than other forms of communication because both parties can exchange information in the communication process as well as direct feedback from both of them according to their respective functions.

\subsection{Doctor's Interpersonal}

\section{Communication Based on the Principle of Openness.}

The results of the study on doctor's interpersonal communication based on the principle of openness, more patients were in the unfavorable openness dimension, namely 45 people (55\%) and fewer were in the good category as many as 35 people $(45 \%)$. Bivariate analysis using the Chisquare fisher exact test obtained $\mathrm{p}$ value $=$ 0,000 , meaning that there is a relationship between personal communication based on the principle of openness to patient satisfaction in the inpatient room of the Royal Prima Hospital Medan.

Openness (Oppenness) is the ability to open up the doctors of the Royal Prima Medan General Hospital in terms of disclosing clear information about health, giving spontaneous reactions to patient / client responses, and delivering responsible information. Openness (Openness) refers to at least three aspects of interpersonal communication. First, effective interpersonal communicators must be open to the people they interact with. This does not mean that one should immediately open up all of his biographies. The second aspect of openness refers to the communicator's willingness to react honestly to the stimulus that comes. The third aspect concerns the "ownership" of feelings and thoughts. To be open in this sense is to admit that the feelings and thoughts that you express are indeed yours and you are responsible for them.

Hutagaol's research results show that the openness of health workers in communicating on family satisfaction of outpatients at Pandan Tengah Health Center. The results of Siregar's research show that the lack of openness of doctors in communicating with patients makes patients feel dissatisfied with the health services provided, patients feel that doctors are not open in explaining the disease suffered by patients, it will make the patient's family disappointed with the service provided by the doctor.

\subsection{The Influence of Doctor's Interpersonal Communication on Patient Satisfaction at the Royal Prima Medan General Hospital.}

The analysis results of the chi-square fisher exact test explained that there was no influence between doctor's interpersonal communication on patient satisfaction at the Royal Prima Medan General Hospital with $\mathrm{p}$ $=0.002$ meaning that there was a very significant influence between doctor's interpersonal communication and patient satisfaction.

According to the researchers' assumptions, doctor's interpersonal communication is a value that must be maintained because interpersonal communication is a tool that can affect the quality of health services if increased health services affect the satisfaction of inpatients. When patient satisfaction is achieved, it will increase the number of patients who come for treatment at the Royal Prima Medan General Hospital.

\section{REFERENCES}

1. Adhani, Rosihan. 2014. Etika dan Komunikasi Dokter-Pasien-Mahasiswa. Grafika Wangi Kalimantan. Kalimantan Selatan.

2. Amirah. 2014. Hubungan Komunikasi Dokter-Pasien Dengan Kepercayaan, Kepuasan Dan Loyalitas Pasien Instalasi Rawat Jalan Rumah Sakit di Makassar. Tesis. Unhas Makasar.

3. Caresya, galdhisia. 2016. Pengaruh Komunikasi Interpersonal Dokter GigiPasien terhadap Tingkat Kepuasan di Poli Gigi Puskesmas Jember. e-Jurnal Pustaka 
Kesehatan, vol. 3 (no. 3), September, 2016. Universitas Jember.

4. Devitto.2014. Komunikasi Antar Manusia (Edisi Kelima). Profesional Book. Jakarta.

5. Hutagaol, Damelta. 2014.Faktor-Faktor Yang Berhubungan Dengan Komunikasi Interpersonal Tenaga Kesehatan Terhadap Kepuasaan Pasien Rawat Jalan Di Puskesmas Pandan Kabupaten Tapanuli Tengah Pada Tahun 2014. Skripsi. USU.

6. Departemen Kesehatan RI. 2014. Pedoman Pelaksanaan Program Rumah Sakit Sayang Ibu dan Bayi (RSSIB). DepKes RI. Jakarta

7. KKI. 2015. Konsil Kedokteran Indonesia Standar Kompetensi Dokter Indonesia. Jakarta.

8. Liliweri,A. 2015. Komunikasi Kesehatan. Pustaka Pelajar. Yogyakarta.

9. Nasir, Abdul. 2015. Komunikasi Dalam Keperawatan Teori dan Aplikasi. Salemba Medika.Jakarta.

10. Siregar, Debi Faradhita Y. 2016. Komunikasi Interpersonal Paramedis dengan Keluarga Pasien Pengguna BPJS (Studi Kualitatif Kepuasan di Rumah Sakit Umum Bina Kasih Medan). Skripsi.USU.

11. Siregar, Nina Siti Salamaniah. 2016. Komunikasi Terapeutik Dokter dan
Paramedis Terhadap Kepuasan Pasien Dalam Pelayanan Kesehatan Pada Rumah Sakit Bernuansa Islami di Kota Medan. Disertasi. Universitas Islam Negeri Sumatera Utara.

12. Sugiyono. (2017). Metode Penelitian Kuantitatif, Kualitatif, dan R\&D. Bandung : Alfabeta, CV

13. Syafitri, Adinda. 2014. Komunikasi Antarpribadi Pasien Dan Dokter (Studi Kasus Komunikasi Antarpribadi Pasien dan Dokter di Poli OrthopaediRSUP H. Adam malik medan). USU. Medan.

14. Tjiptono.2016. Strategi pemasaran edisi 11.Yogyakarta: Andi Offset .

15. Wulandari, Fitria. 2016. Hubungan Antara Komunikasi Dokter-Pasien Dengan Kepuasanpasien Rawat Inap di RSUD Sukoharjo. Universitas Muhammadiyah Surakarta. Yogyakarta.

How to cite this article: Sariputri A, Nasution SLR, Girsang E et.al. Analysis of the influence of an interpersonal communication doctors specialist on patient satisfaction in investigation. International Journal of Research and Review. 2021; 8(1): 1-10. 